\title{
Two Models of Verbal Humor in Hebrew and English Adaptations to the Fairytale Ramplestilskin A Comparative Approach
}

Maya Frutchman ${ }^{1}$

${ }^{1}$ Bar Ilan University, Ramat Gan, Israel.

ARTICLE INFO

Keywords:

\begin{abstract}
This article is a comparison between two writers of children's literature especially their two modern Adaptations to the fairytale Ramplestilskin. These writers are, Abraham Shlonsky, a Hebrew poet who wrote for children as well and Eleanor Farjeon, a unique English writer of children's literature who is considered one of the $20^{\text {th }}$ century's most prominent authors for children. The comparison will be held between Shlonsky's play of the 1960's Utz Li Gutz Li ("Callme Smallme") and Farjeon's novel "The Silver Curlew".

Both works are founded on humor, especially verbal humor, differing between the two authors. Shlonsky uses a humor that is manifested in a diversion from idioms and customary phrases, nonHebrew words and newly invented words. His work is mostly based on morphology and the dictionary. Farjeon is more prone to homonyms and structures containing double meaning that are a recurring motif in the work. This article will demonstrate these different techniques - the similar and the dissimilar in the creation of humor.
\end{abstract}

\section{Two Models of Verbal Humor in Hebrew and English Adaptations to the Fairytale Ramplestilskin , A Comparative Approach}

In this article I intend to compare two adaptations of a folk-tale into stories for children, in Hebrew and in English, by two writers - Abraham Shlonsky, a talented and important Hebrew poet who wrote for children as well, and Eleanor Farjeon, a unique English writer of children's literature who is considered one of the $20^{\text {th }}$ century's most prominent authors for children. Utz-li Gutz-li (Callme Smallme) by Shlonsky (Shlonsky 1974) is a rhymed play and the other, "The Silver Curlew" (Farjeon 1953) is a children's novel ${ }^{1}$. Both books contain a great deal of humor, mainly

1. It should be noted that Farjeon initially wrote "The Silver Curlew" as a play in the late1940, and later adapted it into a novel. 
verbal, based on pun ${ }^{2}$. This humor is aimed at adults and children alike, at times at the former alone, highlighting a unique approach to folklore and children's literature. My choice of Shlonsky is obvious for me - hs is a master of words and verbal humor in my country. I have chosen "The Silver Curlew" because I translated that English book into Hebrew in the past (Agmon, 1959 - see Fruchtman 2001), and because it is appropriate to the subject of comparison and its verbal humor dictates its discourse and vice versa.

Both works are based on a popular legend with a familiar plot - the story of a miller's daughter who became queen due to her assumed ability to spin (usually to spin straw into golden thread). In her despair, a little imp - a wicked midget, or some other despicable creature, rescues her, in return for which he wished to subjugate her or her first-born or both. After she pleads and begs him, the wicked little creature offers a riddle he believes she will never solve - the young queen will be saved, if she finds out what his name is. Rumpelstilskin by the Grimm brothers was a good example of such a name.

In every version and adaptation of this folktale into a story, pride and boastfulness fail the evil creature (though he fulfills his share in the contract and helps the royal miller's daughter). Due to these traits of his, kind helpers reveal his name to the young girl. All is well that ends well - the evil creature destroys himself or disappears, while the royal family and the nation live happily ever after.

Many writers have been attracted by this legendary element, basing stories for children and sometimes for adults on its framework and on those of other legends. Utz-li Gutz-li (Callme Smallme) by A. Shlonsky and "The Silver Curlew" by E. Farjeon are both based on the story of the miller's daughter.

Shlonsky's rhymed play is about a miller's daughter embroiled by her father's boasting that she can spin straw into gold. A little midget helps her and supplies the gold coins for the king. The riddle he applies to the young girl, as a means of freeing herself from his hold, is the same as the one mentioned above. In Shlonsky's version the creature reveals his secret name, Utz-li Gutz-li (Callme Smallme), when he dances and sings it in his faraway district, bragging of his triumph in posing a riddle she will never solve.

Farjeon's story is based on an ancient legend circulating in the Norfolk region of England, dealing with a miller's daughter who boasts of her ability to spin a dozen huge balls of flax into golden thread within an hour. Hearing of this, the king of Norfolk extends a threat and a promise in one; if the miller's daughter lives up to her promise - she will be crowned queen of Norfolk, and if she fails - "Off with her head!" A black imp helps her achieve the impossible task twice in return for the enslavement for her daughter and herself, unless she can guess his name. Eventually the miller's daughter succeeds in revealing the aspired name, "Nimmy-nimmy-not" and the imp fails, as often is the case in fairy-tales.

2 Regarding this kind of humor, see Chiaro( 1992) \& Attardo (1994). 
These are the narrative frameworks in the two compositions. Both versions are based on verbal humor in different variations. It is important to stress that both a play, that requires a dynamic plot on the stage and a novel for young readers, require comic situations in order to appeal to the audience or the reader, since the verbal manipulation alone may prove to be tedious (Van Der Wsthuizen 2007). Shlonsky's play contains comic situations; humor based on mobility on stage and sounds that help ease the audience through the complex and difficult text. Farjeon's story is of a fluent plot. Its characters and their deeds are comically depicted, the pun and verbal humor gracefully applied to the composition.

It is an intriguing fact that both writers chose verbal humor as the leading factor in their adaptations. This type of modern, humoristic presentation of folk-tales is quite common and perhaps the ironic perspective into primal and dismal human impulse evokes this approach toward folk-tales in writers.

As I've mentioned, Shlonsky is a prominent poet in the generation that followed Bialik and Tchernichovsky, a linguistic virtuoso, an inventor of new words (in the 2,000 year hibernated Hebrew language) and a constant employer of verbal compositions founded on alliterations and phonetics - all these, of course, in guise of rhythm and rhyme. He possesses a sharp wit, constantly put to use in the play in question. For example (the original text is in Hebrew) ${ }^{3}$ :

Dominion reads in the book of events:

A two tailed donkey was born

Shall we allow, yes or no,

Two tails him to adorn?

In tailville village two days ago

The king pondering, yes or no? -

As is his way, and asks:

A donkey as nature prevails

Is born with - how many tails?

Dominion: $\quad$ Just one.

The king: $\quad$ And two?

Dominion: $\quad$ A total ass is due.

The king: $\quad$ And is there danger of ill fate to the safety of our state?

\footnotetext{
${ }^{3}$ We tried to translate the examples by a liteary translation, keeping the spirit of the original text.
} 
Dominion: $\quad$ Almost none... unless indeed

The donkey should aspire to lead.

The king: Well then, that's that but this do hear:

I command all tails remain in the rear!

(Utz Li Gutz Li, p.18)

This little passage is typical of Shlonsky, utilizing humor and irony in presenting the problems the king is faced with (the humor is aimed at children as well as the story itself, the irony however, is for the adult readers). The Hebrew version of the play demonstrates Shlonsky's technique being a constant deviation from Hebrew collocations and idioms (see Toury \& Margalith 1973). In Hebrew the same word "donkey" encloses both meanings - the animal and the derogatory description - similar to the English word "ass". An example of this is the use of a Hebrew expression, which literally means a double donkey or an "ass of Asses" (translated above as "total ass") - and the meaning is a total fool. The irony arises from the fact that the description is of a literal donkey in this case

Another example is the following (p .25):

Financio:
Taxes and levies,
But what can you do,
If you're all out of pockets,
And payments are due?

Once more, Shlonsky breaks a well-known Hebrew aphorism "kalu kol hakitzim" (literally: out of ends; implication: all is lost) by switching two phonetically close sounds ("s" for the sound "tz") in the Hebrew words "kisim" (pockets) and "kitzim" (ends) playfully creating duality. Shlonsky relates to the pronunciation and the humor of generation born in Israel called Sabras (see Baruch 1986)

In addition to the humoristic deviation of idiomatic expressions (Turi and Margalit 1973 \& Sternberg 1976) Shlonsky also invents new words, for instance (p.22):

My advice is but one and one alone:

We must find a lady to settle a throne;

A housewife is such a wonder

In avoiding irreparable squander. 
The word Shlonsky uses for squander ( $\underline{\text { bazbezot }})$ derives from the same Hebrew root as the word waste in Hebrew ( $\underline{\text { bizbuzim }}$ ), but is altered, apparently in order to sustain rhyme with the previous bar but also as another occasion of verbal humor. ${ }^{4}$

Shlonsky, who always maintained that children should teach the adults their language just as the adults instruct them in theirs (Shlonsky, Yalkut Eshel p.159 and also Fruchtman 2000 p.133, 138-139), doesn't fail to present his deductive approach in this play, for example

$$
\begin{array}{ll}
\text { The king: } & \text { Ah, charity... 'tis fatal! } \\
\text { The servant } & \text { - explaining to the children: } \\
& \text { Fatal, as taught was I } \\
& \text { Means something like: Oh my! }
\end{array}
$$

And later on:

Dominion: Well I'll exclaim with no apostrophe:

My king's condition nears catastrophe!

The servant - explaining to the children:

And catastrophe means apparently,

Terrible trouble or grievous calamity.

And more: $\quad \ldots$ thus the kingdom sinks

Up to its chin in deficit...

The servant That means loss as Hebrew teaches it.

It is evident that Shlonsky founds the play on humor resulting from the breakdown of familiar idioms, collocations and expressions, the creation of new words and also the use of foreign words, which amuse the younger audience, followed by deductive elucidations. Despite the many explanations, the play is highly sophisticated and employs humor and irony that address adults. It must be stressed that it is the men in Shlonsky's play who dictate the rules. The king dislikes the waste of money, therefore he orders his son to marry a woman who can spin the necessary thread. Women, apart from the clever miller's daughter, are presented as stupid and ugly creatures that are concerned with naught but clothes.

In "The Silver Curlew", Farjeon introduces a great deal of humor as well. Farjeon's humor presents itself in the form of jocular situations (see Baruch 1985), although mainly verbal (pay special

4 Regarding the configuration of revised words in Shlonsky's composition for children "The Tales of Micky Mahoo", a technique typical of his work in its innovative quality, both according to norm and through deriving from it (see Efrat 1996) as well as Shlonsky's approach to collocations and the process of breaking them up, and also about his humor (see: Fruchtman 1983,2000 and also Markus 2002). 
attention to Fruchtman \& Baruch 1983, Markus 1994, 2002, Fruchtman 2000, 2013). She lures her readers into an enchanted world of imagination populated by bewitched creatures, fairies and elves, vis a' vis practical people of predictable behavior. The leading characters in the story are of an earthly quality - Doll and Poll, the miller's daughters; the lady-miller ${ }^{5}$ rather than the traditional male-miller, a vivacious woman named Mother Codling who supports six children - four robust but somewhat dense country lads and two girls (as has been mentioned). This story, unlike Shlonsky's play, seems to orbit a feminist core, written at a time when this was unprecedented in children's literature. Doll, the eldest, is described as pretty and lazy. She is the character who is entangled in the recurring spinning declaration. It is hard to account for Doll's declaration, bearing such crucial impact on her life, other than to dismiss her as stupid (although eventually she proves to possess some practical intelligence). Another central character is the king whose threat of beheading Doll upon her failure leads us to perceive him as cruel or obtuse. The king is presented as a childish, mentally and emotionally defective young man, totally dependent on his nanny, who is depicted as the exact opposite of Mother Codling, the lady miller. The two are in constant competition over the influence on the young queen and the upbringing of her baby daughter. The king is described as a kind of "Dr. Jeckyl and Mr. Hyde" - as double natured in his behavior, which explains his insistence on the spinning.

This story, like Shlonsky's, finds a practical axis in the search for a suitable wife for the king. Since both kingdom and king are in dire need of 12 huge bundles of flax to replenish the kingdom's tattered stock of linen and towels and no woman can be found who masters the craft, the king is really interested in marrying a woman who can spin regardless of her social standing. From his point of view he is doing the right thing, and his cruelty is partly justified by the shortage of fabrics. Contrary to this earthly world, the story presents an imaginary world of fantasy in the form of a strange and legendary man who descended from the moon (The man in the Moon - a local legendary creature) and who longs for the night fairy, his love, who followed him disguised as a beach bird named "curlew" due to her beak that resembles the crescent moon. This strange man is named Charlee Loon (loon - besides rhyming with "moon" it is also similar in sound to the Latin word "luna", the origin of "lunar", meaning moon).

Several other fairies are present at the royal wedding and the christening of the baby, arousing an association with other fairy tales such as Sleeping Beauty. The legendary atmosphere is enhanced by the rhymed verses stemming from folklore and portraying heroes, their surroundings and yearnings. For example (Farjeon 1953, p.189)

"The man in the moon

Came down too soon

To ask his way to Norwich.

5 Just as the miller is female rather than male, so the baby is a daughter and not a son in this version, as opposed to the chauvinist king's wishes and expectations. 
He went to the south

And burned his mouth

By eating cold plum porridge."

A smart and imaginative 12-year old girl named Poll, the sister of the future queen, mediates between the simple material world with all its domestic problems and the world of legend and magic. While the pretty and lazy daughter's thoughts are given mostly to food, her sister Poll leads a rich imaginative inner life often forgetting to eat at all. Poll is the character that makes the acquaintance of Charlee Loon, befriends him, takes care of the fairy-bird and also assists her sister in her plight while driving the childish king completely mad. In the end she receives the most beautiful gift of all, the gift of magic.

The author humorously describes the atmosphere in the palace - the abundance of unnecessary people running to and fro, the Witching Wood, the black imp's territory, with all its disgusting creatures. In contrast exists the simple world of Charliee Loon, who lives on the beach, takes pleasure in fishing and befriending the sea creatures till the time arrives to collect his love and return to the moon. While he lingers, he helps little Poll discover the imp's secret name, Nimmynimmy-not, and save her sister from her horrible fate.

At the plot's center is an English pun, repeated also at the end of the story, as if to create a metaphoric framework - it is what causes Doll to make the mistake of posing as a skillful spinner in the first place. The voracious Doll was put in charge of 12 dumplings, which were intended for the whole family's supper. Her mother instructs her: "Dumplings'll always come again in half an hour" (p.17), meaning that they always bob up in the pot and are ready for consumption in half an hour. Doll's simple interpretation of her mother's words is that the dumplings will literally reappear every half-hour, so she can eat them all, as new ones will come again by dinner-time (p.2 4). At the story's conclusion, when the fairies and the magic dissolve, Poll, the younger daughter and savior, dreams a magical dream interwoven with beautiful folk songs. Whispering in her sleep (p.192): "No, spin Poll's thoughts, not all over, never quite over, come again, it'll come again in half an hour..." which means that it's not the end; memories never cease - they'll come again in half an hour. The different interpretation of the repeated expression becomes the erroneous basis for the whole plot, up to the happy ending.

Another good example of the word-games, especially homophones, based on the double meaning of the word kind: "Unkind? Unkind? Unkind? He shouted. How dare you say I am unkind? Unfair, yes! I am not fair. Unreasonable, I grant you! I have never been reasonable. But unkind? How can I be unkind when that's the kind I am?"

"Poll jumped to her feet and ran at him full tilt. "That's one of the kinds you are, you-you - double - natured brother in law, you!” (p. 91).

Another example of the verbal humor that touches upon one of the main themes of the story is the word spinster; the author utilizes its double meaning both of an unmarried woman and a person who masters the art of spinning. Proud of her craft, the King names Doll "the champion 
spinster in East Anglia", on which she replies: "And don't I wish I was a spinster again! (p.91)". By using the word 'spinster' the King refers to her spinning, while Doll refers to her state of being unmarried: would she not lie and tell the king she was a spinster (can spin), she would be left a happy spinster (unmarried woman), and would be spared all her troubles.

Comparing Farjeon's humor with that of Shlonsky, it is clearly evident that homonyms - words that sound the same and differ in meaning - are the center of her composition, so are the ambiguity, the double meanings, in general. Most of Farjeon's humor is rooted in the misinterpretation of words, such as Doll's misunderstanding of her mother's words, actually dictating the course of the story. Although this kind of humor seems to be sophisticated and intended for grownups, it's also kin to the child reader. Shlonsky, however, resolves the difficulties his humor style presents by rhyming his lines gracefully and by dedicating special explanations for children. Both Shlonsky and Farjeon, like all great artists, demonstrate a trust for the young audience. By not hindering the sophistication and richness of their writing to accommodate children, they prove their audience to be resilient and worthy in their eyes.

\section{Bibliography}

1. Agmon, M. (1959), Xermeshanit ha-kesef (The Silver Curlew), edited by Chaim Abrabaya, Tel Aviv: Machbarot Le-sifrut (Levin Epstein 1972, Zmora, Bitan, Modan 1980). (In Hebrew)

2. Attardo, S. (1994), Linguistic Theories of Humor. Berlin and New York: Mouton.

3. Efrat, M. (1996). Poetic's Licence and Rutine's Licence, in Bar Asher, M. (ed), Linguistic Studies in Hebrew and Judaic Languages. Jerusalem: Magnes. (In Hebrew).

4. Baruch, M. (1985), Types and Topics in Children's Poetry. Tel Aviv: Ministry of Defens Press. (In Hebrew)

5. Baruch, M. (1986), "Phonetic Problems of Young Children - One Component of Humor in Children's Literature, in: Bergson G. (ed) Sifrut Yeladim Vanoar 49, Jerusalem, pp. 36. (In Hebrew)

6. Chiaro, D. (1992), The Language of Jokes. London and New York: Routledge. Toury, G. \& Margalith, A.(1973), On Deviant Uses of Collocations, Ha-Sifrut (Literature) vol.4, pp. 99-129. (In Hebrew)

7. Baruch, M. and Fruchtman M. (1983), Stylistic Studies in Children's Poetry. Tel-Aviv: Papyrus. (In Hebrew)

8. Markus, Y. (2001), Linguistic Patterns for the Creation of Comic and Satiric Effects in Modern Hebrew Fiction. Beer Sheba: Ben Gurion University of the Negev Press. (In Hebrew)

9. Fruchtman, M. (1983), Homonyms as One Humor component in Children's Literature, in: Bergson G. (ed) Sifrut Yeladim Vanoar 36, Jerusalem, pp.17-21. (In Hebrew)

10. Fruchtman, M. (2000), Stylistic Studies in Modern Hebrew Poetry. Beer Sheba : Ben Gurion University of the Negev Press. (In Hebrew)

11. Fruchtman, M. (2013). Children's Literature. In: The Encyclopedia of Hebrew Language and Linguistics (EHLL)I. Ed. Geoffrey Khan. Leiden. Boston: Brill, 422-425.

12. Farjeon E. (1953), The Silver Curlew. Great Britain: Oxford University Press.

13. Farjeon E. (1960), The Glass Slipper. Great Britain: Oxford University Press. 
14. Farjeon E. (1935), A Nursery in the Nineties. London: Victor Gollancz Ltd.

15. Thomas, E. (1997), The Last Four Years: Eleanor Farjeon. Great Britain: Guernsey Company Press. (Revised edition)

16. Napoli D., \&Tchen, R. (2001), Spinners. USA: Puffin Books (Penguin Group).

17. Ravid, D. (1994), Language changes in Child and Adult Hebrew: A Psycholinguistic Perspective. New York: Oxford University Press.

18. Tibbets, S. (1973), What's So Funny? Humor in Children's Literature, California Journal of Education. Research 24, 1: pp. 44-46.

19. Shlonsky, A. (1960), Yalkut Eshel - Articles. Jerusalem: Sifriyat Poalim. (In Hebrew)

20. Shlonsky, A. (1964), Uts Li Guts Li. Tel-Aviv: Am Oved. (In Hebrew)

21. Tsao,Y. (2008). Gender Issues In Young Children's Literature. Academic article, Reading Improvement, 2008 - Cite seer, PDF, the Pennsylvania State University. https://pdfs.semanticscholar.org/d722/00d6dd74289c3cc434e308cb25e80500469b.pdf

22. Van Der Wsthuizen, B. (2007). Humour and the locus of control in The Gruffalo. Journal of Literary Criticism, Comparative Linguistics and Literary Studies. Vol. 28 (3), pp.5574. 